\title{
THE FEATURES AND TYPES OF UNIVERSITY STUDENTS' FROM THE VIEWPOINT OF TEACHERS
}

\author{
Beatrix Fűzi \\ Budapest Business School University of Applied Sciences, Hungary \\ Erzsébet Jármai \\ Budapest Business School University of Applied Sciences, Hungary
}

\begin{abstract}
Higher education is struggling with the consequences of "mass production" that has become characteristic in recent decades. The challenges include large group sizes, impersonal teacher-student relationships, an increase in the number of students with specific learning difficulties. Our research and development project (EFOP-3.6.1-16-2016-00012) aims to help teachers in economics programmes in the formation of attitudes supportive of students and in the development of the efficiency of teaching.

We intended to explore teachers' perceptions of the students, with special attention to their motivation and the characteristics of the learning. We were curious whether teachers identify various student types, and if they take into consideration them in their teaching activities. (We asked students to provide self-characterisations along the above mentioned factors in order to make a comparison between the teachers' and the students' perspectives possible.)

We surveyed teachers of six Hungarian universities. The questionnaire was completed by 210 university teachers. We also supplemented the above with the qualitative analysis of 42 in-depth interviews conducted with teachers.

Almost all teachers agreed that there is a perceptible increase in the differences between students. The teachers' responses outlined a few student types, as well as some typical attitudes in reaction.

While the majority of the teachers approach the experienced phenomena as a challenge, or at least as a task to tackle, and are therefore actively looking for solutions, a smaller proportion considered them as unsolvable problems, and therefore do not even experiment with solutions.

The interviews with the teachers shed light on the significant differences in terms of how nuanced the teachers' images of students are. We incorporate our findings into trainings for teachers.
\end{abstract}

Keywords: university students, university teachers, motivation, learning, student characteristics, higher education of economics. 


\section{Introduction}

The stakeholders of Hungarian higher education are dissatisfied. One of the consequences of the series of reforms over the past three decades is "mass production," as a result of which the composition of the student population has changed significantly: it has become more diversified, and differences between students increased.

Prestigious and famous universities pick out the best, highly motivated students. Younger universities, most of which were originally colleges, enrol a large number of less motivated students with average academic performance in order to obtain or keep state financing.

As a result, teachers at universities encounter lower levels of preparation and motivation on the part of the students, while in connection with themselves they feel that they are not adequately prepared to handle the diversity and the large number of students.

When we ask students, however, it turns out that, from their point of view, the low motivation is, to a large extent, the consequence of the teachers' attitudes and obsolete teaching methods. (Fúzi, 2019)

As such, the two sides are blaming each other. The problem is well manifested by the fact that, in addition to the large drop-out rate, the enthusiasm of students remaining in the programmes also significantly decreases over time (Solt, 2018).

Our university is currently striving to address this phenomenon in two ways. On the one hand, it offers special remedial courses and other forms of support to students. On the other hand, it is engaged in a wide-scale research project among teachers and students on the topics of motivation, the use of ICT tools, as well as the application and experiencing of teaching methods, the results of which are channelled into teacher training courses and publications on teaching methodology. Our paper presents a segment of this research project.

\section{Approach and background}

\section{Results related to Hungarian higher education}

Briefly, we wish to mention the Hungarian problems concerning higher education, which also occur in other institutions of the European Higher Education Area.

The accelerated technical, economic, social and value changes that started in the $20^{\text {th }}$ century did not leave higher education untouched either. In connection with the enrolment expansion, Hrubos $(2014,541)$ underlines that the massified higher education is not sustainable in the manner used 
before this expansion process started. Although the problems are sensed by all stakeholders and there are also efforts for finding solutions, responding to the challenges occurs slower than would be necessary.

Derényi $(2018,133)$ points out that teachers are faced, on the one hand, with changes in the students, and on the other hand, they experience that their traditional methods are no longer sufficient in teaching students. The composition of the student population also transformed significantly in recent years. The number of students applying and admitted to higher education in the year of their graduation from secondary school has increased (see Figure 1). Due to the decrease of willingness to apply later and of the proportion of those involved in part-time programmes, the average age of freshmen is younger than before. The most talented students try to get into universities in the capital and in other big cities, as well as abroad.

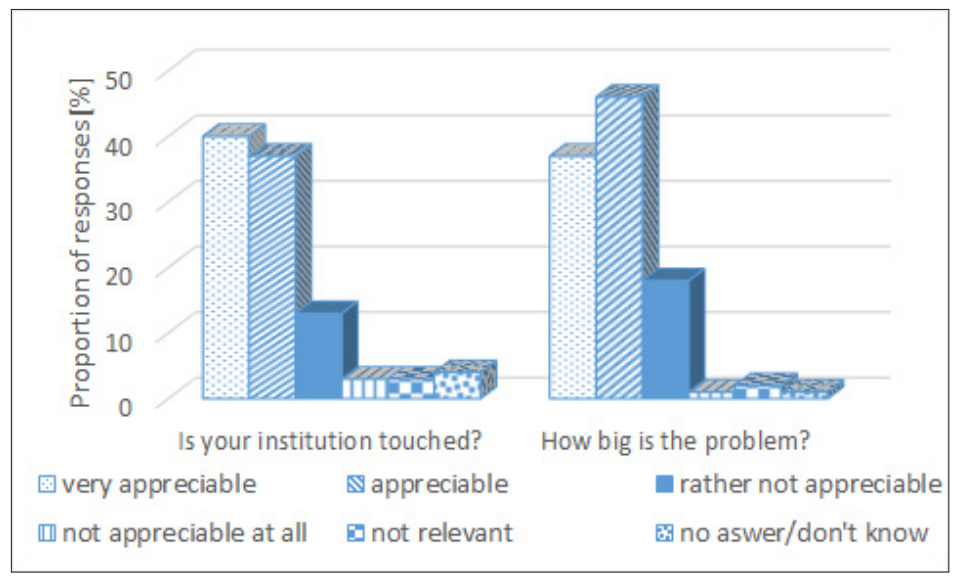

Figure 1. Teachers' perception of the decrease in admitted students' prior knowledge (2014). Source: Derényi, 2018, 142 Based on the data of outstanding project named TÁMOP-4.1.3.

By taking the matriculation examinations, everyone earns the right to enter higher education, which is thus available not only to students in elite education programmes (Kocsis and Koltai 2006, 190, qtd. by Simándi 2016, 18). The student population can be considered as heterogeneous from different points of view: not only in terms of their age, but also their level of prior studies, for example, it is not infrequent to have students working towards their second or third degrees. An increasing number of students also have jobs, which means different work-related experiences on which teachers can build, but there will be also students in the same group who never had a job anywhere before. The so-called non-traditional students also include those who are older, have families, live with disabilities, or 
have special education needs (SEN), and teachers are not professionally prepared for these students at all (Kopp, 2013, qtd. by Simándi, 2016, 18). It is not surprising that, in addition to the increasing number of students, the heterogeneity of the groups also makes teachers' work more difficult, as it would necessitate methodological adaptivity and differentiation.

Another factor contributing to the diversity of students is that in the course of their admission procedures - with the exception of a few programmes where aptitude tests have been introduced - there is no screening of students (Derényi, 2018, 134).

Balázs $(2014,551)$ considers it a legitimate criticism against higher education institutions that, because of the "per capita quota," they admit anyone, which leads to a significant decrease of the quality standards. Students not suited to higher education hinder the learning progress of talented and committed students. They put additional burdens on the teachers, which distracts them from academic and research activities. In his opinion, it cannot be expected from universities to help students who are lagging behind from secondary schools by offering remedial courses.

In recent years, some isolated initiatives, educational innovations have been started, associated with individual subjects, courses, or specific teachers. Some universities strive to offer trainings and other forms of support developing education for its teachers (Derényi, 2018, 139).

Teachers in higher education would be more willing to make efforts for better quality education if they experienced a minimal level of motivation from students for learning. In the different institutions, especially driven by the individual efforts of leaders and teachers, some very promising and interesting innovation processes are being realized, but their maintenance and the dissemination of their effect is unsolved and lacking in resources (Derényi, 2018, 145).

\section{Local and international research concerning changes in higher education and students}

Given the large number of international research projects concerning the characteristics and motivations of the current generation of students, the effects of the use of electronic devices, or the methodological development of higher education, we can assume that the phenomenon examined is not a local one. In the following, we will briefly refer to some of these projects that provided ideas for us when designing our own research.

Khalid (2013) conducted interviews with teachers considered by students as excellent and recognized for their work with awards. He tried to identify which classroom activities and teaching styles raise interest among university students. The use of teaching methodological elements 
considered effective by the interviewees was also justified by student characteristics and needs. It transpired from the responses that what the majority of students need is not solution of tasks modelling reality, but real tasks, active participation in the processing of the course material, as well as regular and substantive feedback. Further, they are seeking for opportunities for the practical application of the course material.

In her research, Lubicz-Nawrocka (2019) examined the characteristics of what students perceived as excellent teaching. On the basis of her results, it can be concluded that students attribute a key role to teachers in education of outstanding quality. They sense and appreciate teachers' efforts and enthusiasm, as well as their support given to students.

The studies of Vermunt and Minnaert (2003, qtd. by Kálmán) show that the learning style and characteristics of students change a lot over the course of their university years. Further, Vermunt (1996) proved that context also affects the learning behaviour. He found that persons already possessing work experiences, who generally applied the deep-processing learning strategy, start to apply the reproduction-directed strategy once again when they return to formal education settings. It follows from the above that it is difficult to provide a generally valid characterization of students. Therefore, it is advisable to ask teachers to give characterizations of their specific groups in order to find out whether they sense the differences between the different groups and years of students. On the other hand, it is difficult to separate which characteristics are the students' own and which are the elements activated by the environment.

Fábri (2014) examined students preparing to start their studies in higher education and collected their expectations and needs, which are the following:

- the up-to-date nature and applicability of the materials taught;

- the helpfulness of the teachers;

- the quality of the theoretical education and the high standard of the teaching (page 162);

- the relationship between students and teachers in general;

- possibilities for professional scholarships, talent management (page 233).

Magyari (2010) is of the opinion that the negative experiences of teachers regarding students, such as the belief that they are unmotivated, mainly arise from the loosening of parental and teachers' control, from the university student lifestyle.

In 2008, the National Union of Students prepared a survey among students at British universities concerning their experiences of life at universities (NUS Student Experience Report, 2008). A total of 3,135 students from 146 higher education institutions participated in the survey. Different types 
of students were identified on the basis of the factors motivating them to attend university (Figure 2).

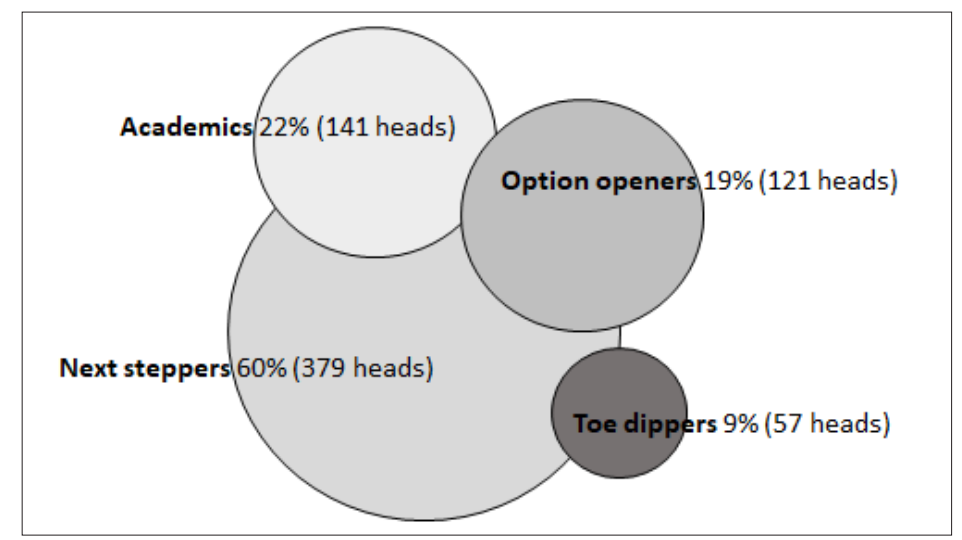

Figure 2. Motivation profiles - Motivations for attending university. Source: NUS Student Experience Report $(2008,6)$

On the basis of our earlier research, we have found a significant link between teachers' effectiveness and their attitudes toward students, both in the secondary school and the higher education sample. Teachers' perceptions of students influence both their acceptance among students and the effectiveness of their work.

Research into how students and those working in higher education perceive each other and themselves as groups is missing and would be necessary.

\section{Research design and methodology}

We present one part of our research project its centre the questions and hypotheses stand mentioned below which were studied by mixed method.

\section{The questions raised}

- What features and types of students can be identified by university teachers?

- What do teacher think of the origin of the changes? Do they assume connection between changes and ICT tools?

- Do teachers have ideas, strategies to handle the students differently and to solve the noticed problems connected to the students?

- What are the „good practices” for make the different student types more motivated?

- Are there differences in the teachers' student image according to the gender, the years of teaching experience, have a teacher degree or not? 


\section{Hypothesis}

- Majority of teachers thinks the tendency of the changes of the students are negative.

- Majority of teachers blame at least partly the enhanced usage of ICT tools for the changes of the students.

- Women, teachers with more experience and certificated teachers mention more positive elements connecting to students.

\section{Data collection and tools}

We developed and used questionnaires for university teachers, also conducted semi-structured in-depth interviews with a smaller group of them.

\section{Survey with questionnaire}

The use of the questionnaires was reasoned by the need to collect data from the largest possible number of teachers covering a diversity of areas. Questionnaires for teachers was improved in such a way that the questions pertaining to the motivational and learning characteristics of students and to the methods used in higher education would be included. The teacher questionnaires were completed online. The data collected were primarily subjected to a quantitative analysis by using SPSS.

\section{Interviews}

We also did semi-structured in-depth interviews with some of the teachers, in order to be able to make in-depth analyses and to further nuance the quantitative results. The interviews were conducted on the basis of a prepared outline, allowing the subjects also to go more into depth in certain topics, depending on their reactions and needs. The transcripts of the interviews were primarily analysed using a procedure of qualitative textual analysis.

\section{The sampling method and the features of the sample}

Starting out from our own institutional profile, the scope of our research project covered teachers and students in economic higher education, because we specifically aimed to provide assistance to them with the findings. The data was collected among teachers in the related programmes of six Hungarian universities. The sampling took place with a combination of the convenience and the snowball sampling methods. We contacted the teachers, through a network of acquaintances and on the basis of lists of addresses collected from the websites of economic higher education institutions, either in person or by way of electronic mail specifically addressed to them. 
The teachers' questionnaire was completed by 210 (57\% female and $43 \%$ male) university teachers. In addition, we also conducted interviews with 42 teachers (44\% female and $56 \%$ male). The sample of respondents was representative for their respective institutions, although not nationally.

The characteristics of the teachers participating in the survey:

The average age of the respondent teachers was 48.5 years (the youngest was 26 and the oldest respondent was 77 years old), the average length of their experience in higher education was 18.7 years (between 1 and 54 years). $51 \%$ of the respondents were certified as teachers, $2 \%$ were in the process of pursuing such studies, and $47 \%$ had no teacher certification.

Features of the teachers who gave answer to the interviews:

The average length of teaching experience of the interviewees was 17.6 years. $50 \%$ of them were certified as teachers, and one person was in the process of pursuing such studies. The interviewees represent the general sample of respondents by questionnaires well. $47 \%$ of them have experience teaching in secondary education as well.

\section{Findings}

On the basis of questionnaires, nearly half of the teachers consider the changes experienced in connection with the students over the past few years and decades as definitely negative (see Figure 3). Less than one-fifth of all respondents have the opinion that the changes in connection with the students are definitely positive. A little over one-third of teachers who answered, have a balanced, more nuanced opinion on the students.

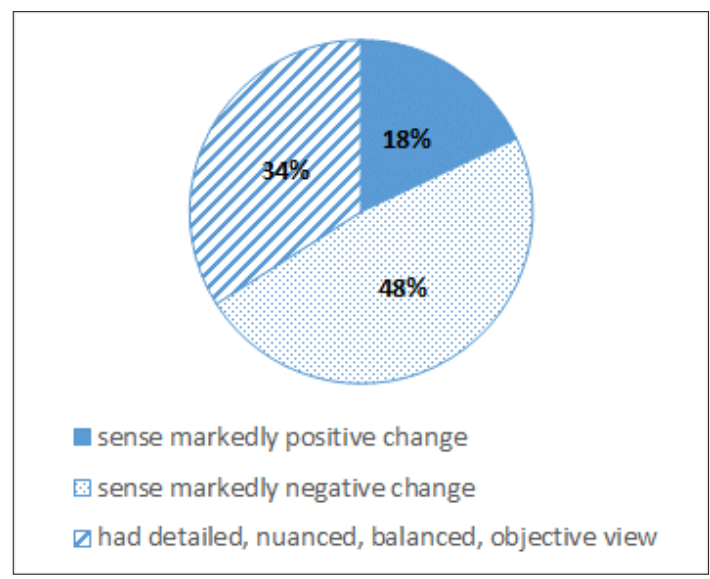

Figure 3. What kind of changes did the teachers sense connedted the students based on the questionnaires (210 teacher respondants). Source: Own adjustment based on the collected data 
In the present paper, we intend to provide a deeper, more refined analysis of the views and opinions of teachers on students, on the basis of interviews conducted.

The interview included a question specifically pertaining to students ("Are today's students different than those before? Please provide your reasons for your answer."), but elements related to students were also formulated at several other points in the interviews. In the texts, we identified 123 elements pertaining to students, which we then systematized on the basis of various criteria.

The first criterion was whether the element was a positive, negative or objective statement as regards students, or perhaps one in which positive and negative evaluations are mixed. Based on the texts of the interviews the majority of the statements were negative. Less than $10 \%$ were positive evaluations of students, while a third of them were objective or containing elements of mixed evaluations.

From the point of view of content, we differentiated between three groups: elements serving the purpose of describing and characterising students (mentioned 89 times); elements related to the relationship between teachers and students (mentioned 15 times); and finally, elements in which teachers also formulated some kind of methodological recommendations and/or proposed solutions to handle the student characteristics sensed by them (mentioned 22 times). (Some elements could be placed in several categories.)

\section{Descriptions of the students}

In the descriptions of students, negative elements dominated once again (74\%). There were also general, simplifying statements, such as "the quality of the students is continuously deteriorating," and in some (a total of four) cases, the interviewee responded to the question with a single adjective. More than $90 \%$ of the teachers, however, explicated their comments related to students at more length, with an average of three specific characteristics mentioned. The most frequently mentioned negative characteristics were the following:

- the decrease of interest, motivation, the lack of commitment;

- the lack of willingness to invest energy and time, which is manifested in missing classes, striving to fulfil only the bare minimum level of requirements, low level of activity, doing something else in class, avoiding activities requiring persistence and concentration;

- lack of independence, responsible behaviour and/or purposefulness;

- gaps in necessary academic grounding, general education, or vocabulary, resulting in difficulties in making associations, incorporating 
new elements; due to superficial knowledge, they are easy to influence;

- underdeveloped skills in the fields of communication, conflict management and teamwork;

- missing desire to conform.

A general teaching methodological consequence of the above is the difficulty of creating and maintaining discipline and attention. In comparison with our prior expectations, generational theories were offered only in few cases as an explanation.

The source of teachers' disappointment related to students is the nonfulfilment of their expectations based on earlier experiences. Few respondents identified positive elements concerning the students in difference from their expectations. What could be in the background of this is that few teachers discover new virtues of students, or maybe because they do not have many such virtues related to their academic activities.

Only $6 \%$ of the abovementioned student characteristics were positive, which are listed below:

- Generation Z is more curious;

- they are more open;

- students are more self-assertive, they know what they want to do for work, and prepare for it consciously;

- their knowledge is different, but we can clearly see the many smart kids and how many things they can solve with their phone, for example;

- in the last two years, students have become more ambitious, they are not as lethargic as a few years ago;

- they appreciate notes on the whiteboard, because otherwise they are just looking at their phones;

- they are better at verbal activities and in presentations.

$20 \%$ of the descriptions of students were objective or included both positive and negative elements. The following are some examples:

- "There are many guileful and soft-soaping students, but then I realized that the well-mannered kids are also there, and they suffer from the former group as well";

- "the majority are busy with some job, and they don't really work while studying, but rather study while working";

- "they have more specific expectations when it comes to the lessons and the course material";

- "the changes in attitudes are rather negative, but as I know this age group, the students of the university belong to the elite";

- "they are pulling in the direction of the corporate world"; 
- "students no longer know what they still knew five years ago, but they are also familiar with technologies that I have no clue about."

In response to the question inquiring about changes in students, there were 15 references to the use of electronic devices as a factor with a strongly influence on student characteristics. Three of these pertained to students confusing knowledge with information that is readily available on the internet. "Just because he pulls up a verb conjugation table on his phone, he won't be able to use in real situations when speaking, this must be learnt." "The use of gadgets appears to be some sort of knowledge, but it cannot substitute for knowledge of a subject." "They think that they can learn everything from the internet and from Facebook."

- According to some teachers, students are practically addicted to their devices (mentioned five times). This was suggested by phrasings such as "they are glued to their gadgets" and "continuous online presence."

- Some respondents drew a link between weakening literacy and the increased use of electronic devices. "They cannot write by hand, and I cannot read their writing, and for this reason I am not willing to give them a paper and pen test, only an electronic one."

- Some respondents firmly believed that the reasons for the changes in the students are not to be found in the digital age. "It is harder not because they are the digital Generation X or Y, but because of the lack of examples that would offer them values."

- Some colleagues prepare for the changes between generations of students consciously and with joy. "I am already preparing for Gen Z students arriving soon; probably they will need a different approach in teaching."

\section{Changes in the teacher-student relationships}

When thinking about the student characteristics, teachers mentioned 15 elements that allow us to draw some conclusions concerning the changes in teacher-student relationships. Among these, teachers reported on negative changes in 7 and on positive ones in 2 cases, while in 6 cases, we received answers containing objective, or both positive and negative elements.

The negative elements were related to students no longer considering their teachers as unquestionable authorities. These includes statements such as "earlier, teachers had authority, but today, students respect teachers less," "they are a bit more disrespectful", "they do not believe that the teachers would say something wise." "What they do not understand is that we provide them with a foundation, and we cannot teach them 
everything specific to a given field, it is not possible." "Maybe they even look down on us (teachers) because we do not have the latest gadgets."

Lubicz-Nawrocka (2019) has different results which mean that there is a key role of teachers in the students' idea of the excellent education. The teachers' efforts, helpfulness, trials to involve students and the direct behaviour of teachers are appreciated by students.

Elements were considered as positive when teachers reported that the more direct teacher-student relationship gave them a good feeling, or when teachers found it a positive experience when they could regularly learn something from their students.

\section{Elements related to teaching methodology}

From the point of view of reducing drop-out rates, it is important to see whether teachers can respond to the changing student characteristics effectively by way of their teaching methods and practices. In their characterizations of students, teachers formulated methodological conclusions in 22 cases. These showed both overlaps and contradictions.

There is a need for the reinterpretation of the teacher's role: the teacher should become more of a mentor, a person facilitating the synthesizing of knowledge. An investment of quality time is needed when the students and the teachers can immerse in the material together. These findings are same to the results of Lubicz-Nawrocka (2019). Achieving a mass change in the current generation of students is not possible, and therefore, teachers need to find a way to adapt. By contrast, there was also a respondent who concluded that "it is not me who needs to change." Many of the teachers welcomed teacher-student relationships becoming more direct, and considered it as a factor improving efficiency.

The introduction of new methods of testing and examination, such as online examinations, points earned continuously during the year on the one hand due to the deteriorating writing skills, and on the other hand because of digital competences becoming stronger. Respondents referred to students' need for content-focused, substantial and positive feedback as an important need and one that needs to be satisfied.

Some of the respondents considered the simplification of the course material, the modification of its language ("translating it into the language of the students"), as well as the reduction of its quantity as possible ways to make progress. In the opinion of other teachers, however, simplification and reduction are not the right direction; the key is to select the right forms and channels through which the course material is conveyed to the students. 
Many respondents consider abandoning the traditional genre of frontal, lecture-type instruction and/or its replacement with digital methods as the desirable way. In the opinion of others, the ICT competences of students cannot be utilized in learning, because "when I wanted to use it for educational purposes, they were shocked," and "they could not decide what is relevant and what is not."

\section{Differences among teacher groups}

We made Khi-square calculations to answer our question whether there are differences among teacher groups according to the to the gender, to the years of teaching experience, to existence or absence of teacher degree. Because of the low number of the participants of the interviews we found interesting frequences but none of them were significant.

Between the male and female teachers were not find differences not even on the level of frequences (see Figure 4). Both group mentioned positive, negative and balanced elements almost in the same amount.

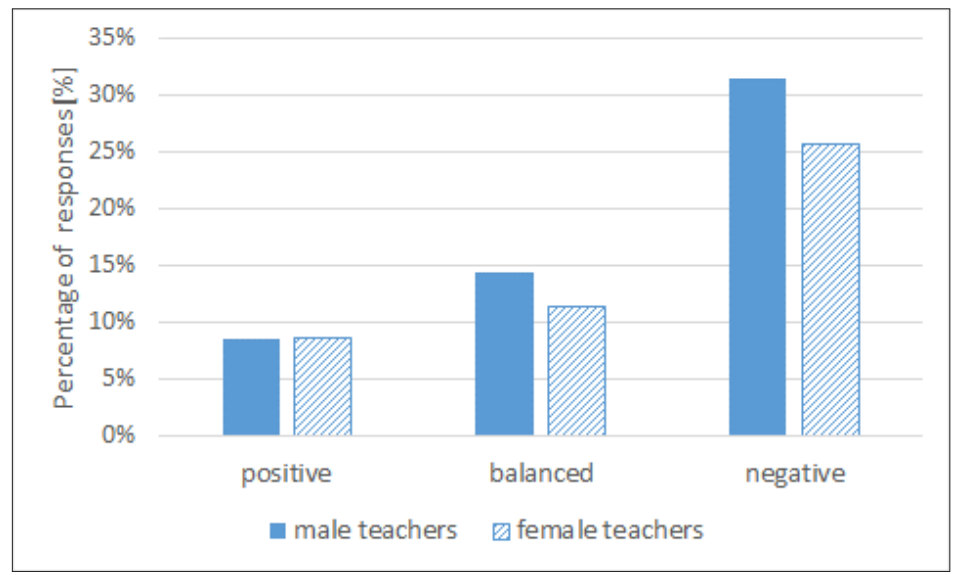

Figure 4. Positive, negative and balanced elements mentioned by male and female teachers about students.

Source: Own adjustment based on the interviews' data

Inspite of the similarities there was one interesting difference. The improving and changing the university teacher role in the direction of accept the student was suggested only by female teachers.

Based on the proportions the beginners sensed more positive features of the students than the more experienced teachers (see Figure 5). 


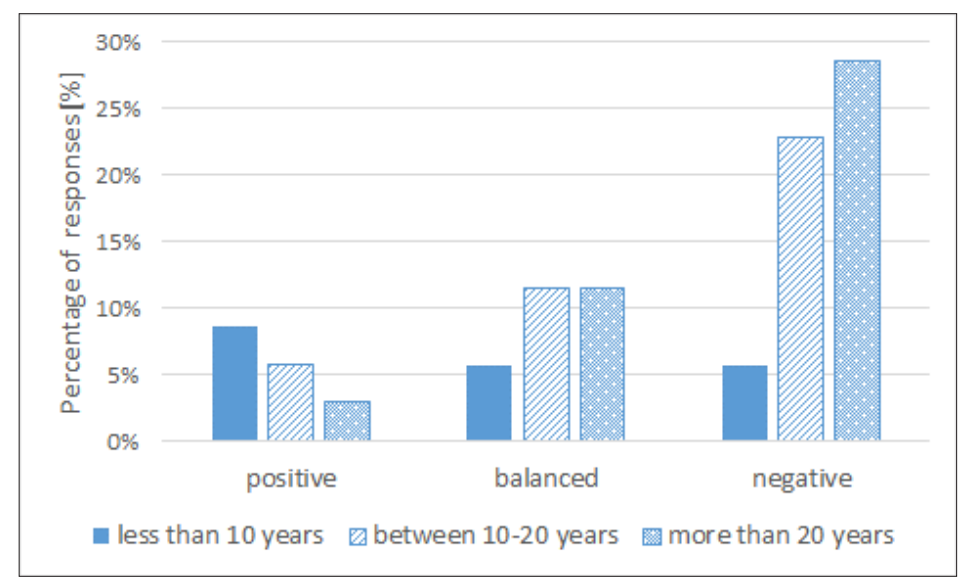

Figure 5. Students' features from the viewpoint of teachers with different experience.

Source: Own adjustment based on the interviews' data

The most interesting difference was found between the teachers who are certificated as a teacher and who are not. The certificated teachers mentioned less positive and less negative features of the students but said markedly more balanced elements than the other group of teachers (see Figure 6).

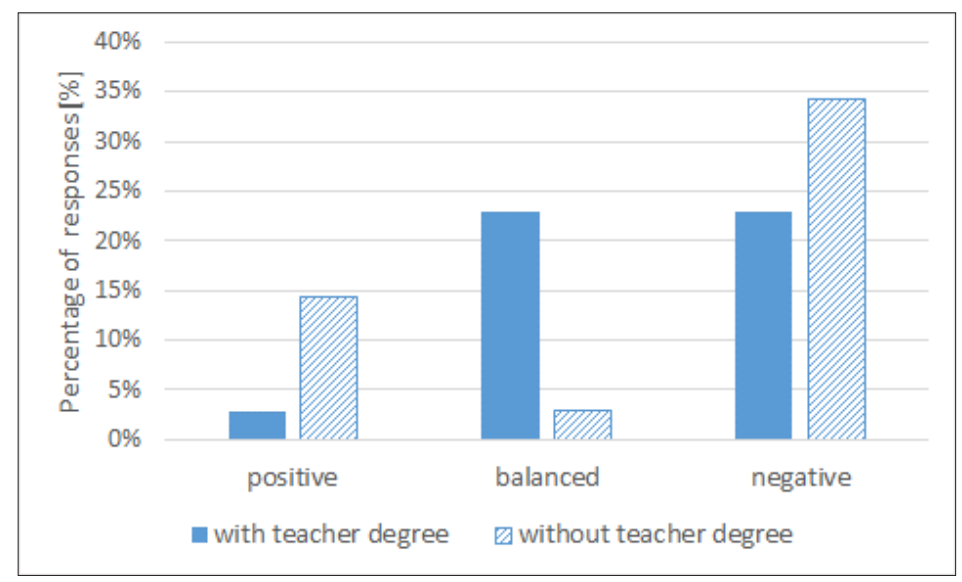

Figure 6. Evaluation of the students' change by certificated and not certificated teachers.

Source: Own adjustment based on the interviews' data

The lecturers without teacher degree sensed the changes of the students extreme. The hypotheses could not reinforced. 


\section{Student profiles based on teachers' opinion}

In some of the interviews, the respondents described student types, characters in a detailed and nuanced way. In the following, we will present some of these.

The positive student character is motivated and purposeful.

One subtype is the typical eminent student, who never questions the content of the course material, does not inquire about purposes, and strives to perform at maximum level.

Another subtype consists of students who prepare their professional careers consciously, and are looking for elements in the course materials that are useful and directly applicable. They are critical, but aiming to cooperate and develop.

More different negative student characters appeared.

Students struggling with difficulties: Students with learning difficulties, special needs, specific learning disabilities. The fulfilment of the requirements poses great difficulties for them. In many cases, their fellow students are also rejecting towards them, because they feel that such students slow down or disturb the process of education. Teachers, on the other hand, are often perplexed about how to prepare or support them.

Life artists: Their university life is organized around good company and partying. For them, the primary benefit of their university studies is not learning but networking. The length of their study is often significantly longer than the original length of the programme.

The scoundrel: A contradictory student category in that they want to graduate, but also want to achieve this in the most energy-efficient way. Cheating, colluding, plagiarizing or other forms of academic dishonesty are not beyond them either, as they try to achieve their aim.

The aimless: An entirely aimless group of students who only study because their parents want them to. It was not their own decision or interest that motivated their choice of studies. They just want to survive the academic programme: they are not looking for any value in it, and often would not even recognize it even if it was right in front of them.

A balanced view of students. It was named „Working beside learning or learning beside working".

An increasingly large number of students also have jobs, either because they need the money to maintain themselves, or as a conscious career building act. They are typically motivated and talented students; however, in the interest of achieving the right balance between work and studying, they strive for a tight, efficient time schedule. They devote as much time to studying as necessary for fulfilling the requirements, and consequently, their results are often behind what could be expected on the basis of their capabilities. 


\section{Teachers' attitudes to new student characteristics}

We also examined what the text of the interviews reveals about teachers' attitudes to students and their characteristics.

In case of the majority of the interviewees it could be felt that they are looking for solutions and have various attempts for handling the changes. The following summarizes the most frequently received answers to the questions aimed at collecting the best practices.

1. Increasing classroom activities and involving students.

2. Taking student characteristics into consideration when designing the course materials.

3. Putting practical considerations, a practice-oriented approach and applicability of the materials into the foreground.

4. Using ICT tools.

5. Strengthening the partnership nature of the teacher-student relationship. In addition, the outlines of a different attitude are also taking shape, representatives of which would prefer to turn back the hands of time. The main elements of this attitude include that universities should be reserved for the best students only, problematic students should be removed, and we should return to the application of teacher-centred methods.

\section{Discussion}

Our results indicate that teachers consider the changes in connection with their students mainly as negative. On the one hand, they assume a devaluation of their own role in the eyes of their students. On the other hand, they experience the facilitation of students' learning as a significantly more difficult challenge. Their perceived situation in which they have to exert increased effort while weakened in their roles may, in the longer run, also decrease their motivations as teachers. These factors - teachers' perception of their role and their image of students - may be suitable for the screening of teachers at risk of being exhausted or burnt out.

Our earlier research indicated positive attitudes toward students correlate with the effectiveness of teachers (Fúzi and Suplicz, 2016). The question arises whether teachers can maintain positive attitudes and if so, how - if they consider students' characteristics as negative as the findings above seem to indicate.

In future research, we plan to examine whether teachers did not discover or mention the positive characteristics of today's students:

- because the interview was a good opportunity for venting complaints, or

- because these are so different from the characteristics of earlier generations of students that teachers do not yet have a sense of these 
as elements useful in education, they do not know how to build on these; or

- because the changes in the current generation of students are indeed only negative from the point of view of teaching and learning.

A limitation is inherent in the fact that we have no information on the quality of the respondents' work. It would be useful to compare the quality of teaching against the teacher's perception of the students. A possible next step would be the observation and analysis of the lessons taught by the interviewed teachers and/or the evaluation of their work by their students. With the help of these methods it could be explored how the teachers' attitudes toward students are manifested in a classroom environment, and how well the best practices and methodological conclusions drawn can work.

The next station of our analytical work will be to compare the self-evaluations of the students participating in the research project with the teachers' perceptions discussed above. We should identify the points where the opinions of students and teachers are the same or significantly different.

\section{Conclusions}

In our paper, we examined the experiences and perceptions of 42 teachers working in Hungarian economic higher education concerning their students, on the basis of semi-structured in-depth interviews with the teachers.

On the basis of the quantifiable results, the majority of teachers considered the changes related to the student population with respect to learning as unfavourable. The learning and the teaching are rendered more difficult, for example, by the weakening of students' motivation and commitment, which causes problems in terms of creating and maintaining attention and discipline. Students' less thorough prior grounding and lack of general knowledge makes it more difficult for new elements of knowledge to be incorporated. Only few teachers identified positive changes. Objective or more balanced descriptions of students, containing positive and negative elements as well, only occurred in one-fifth of the cases.

The qualitative analyses provide a taste of the diversity of teachers' modes of thinking.

The changes related to students were linked by teachers to the digital age and the use of devices to the point of addiction in $16 \%$ of the responses. The majority of these blame these for the deterioration of learning skills. Two respondents mentioned, however, that with the use of these devices, students can be more efficient in problem-solving, and that it is worth learning from them in this respect. 
The teachers interviewed also formulated some conclusions pertaining to the relationships with students and to teaching methodologies. Some teachers feel that students do not consider teachers advantage in knowledge and leadership role as self-obvious. Others, however, welcomed the shift in teacher-student relationship towards more of a partnership. The respondents drew very different conclusions as far as the methods of teaching are concerned. Some would consider a more intensive use of digital devices advisable, while others think it would be best if they were banned. There were respondents arguing for a simplification of the language of the course materials, in contrast with those who believe the channels used for conveying the material are more important.

We highlighted the student types described by the interviewees in quite some detail, such as:

- eminent students;

- critical, purposeful career-builders;

- strugglers;

- life artists;

- scoundrels;

- the aimless;

- students working while studying or studying while working.

We wish to continue our work with a deepening of the analyses, as well as on developing and offering trainings to support the teachers.

In addition, we plan to extend our research to cover the following questions:

- To what extent does the burden borne by teachers, weakened in their roles and exerting increased effort to be effective, accelerate exhaustion and burn-out?

- Can teachers' positive attitudes toward their tasks and the students be maintained, while their perception of the students is negative?

On the basis of our findings, the proposed content of the trainings to be organized for the teachers:

- the selection of methods appropriate to the specific student characteristics;

- the deepening of teachers' knowledge concerning their students;

- establishing a dialogue between teachers and students.

After all we close our work useing the analogy of Professor Pál Michelberger: "We expect birds to fly, swim and run well. Eagles are excellent flyers, but they cannot run or swim, ostriches are excellent runners, but they cannot swim or fly, while penguins are excellent swimmers, but they cannot fly and only waddle. On the other hand, gees can swim, run and fly a little bit, but they are not excellent in any of these. On my part, I would 
like to see more eagles, ostriches and penguins in higher education, and fewer geese." (qtd. in Balázs, 2014:554).

\section{Acknowledgement}

The research project was realised with the support of the European Union from the EU EFOP-3.6.1-16-2016-00012 grant. Poject name: "With innovative solutions for improving efficiency of research and development and innovation actions of Zala county".

\section{References}

Balázs, E. (2014). Tömegoktatás, elitoktatás és a minőség [Mass Education, Elite Education and Quality]. Educatio, 2014/4. pp. 550-554. ISSN 1216-3384.

Derényi, A. (2018). A tanítás és tanulás minőségének javítása az elmúlt 10 évben [Improving the Quality of Teaching and Learning in the Last 10 Years]. In KOVÁTS, G., TEMESI, J. (eds.) A magyar felsőoktatás egy évtizede 2008-2017 [One Decade of the Hungarian Higher Education - 2008-2017]. NFKK Kötetek 2. pp. 130-146. ISSN 2064-7654; ISBN 978-963-503-672-1.

Fábri, Gy. (2014). "Kvalitatív és kvantitatív felmérés, országos és regionális reprezentatív attitúd vizsgálatok, elemzések, kutatás-fejlesztési szolgáltatás" [Qualitative and Quantitative Surveys, Nationally and Regionally Representative Attitude Research and Analysis, Research and Innovation Services] „Felsőoktatási szakpolitikai és fejlesztéspolitikai elemzések az ESZA fejlesztések tervezése érdekében" [Political Analysis for Planning the Development of Higher Education]. TÁMOP-7.2.1-11/K-2012-0005.

Fúzi, B (2019). Should We and Can We Motivate University Students? - The Analysis of the Interpretation of the Role and the Teaching Methods of University Teachers. In Cermakova, K. and Rotschedl, J. (Ed.) (2019) Proceedings of the $7^{\text {th }}$ Teaching \& Education Conference, ISBN 978-80-87927-48-9, ISSN 2570-6551, London, pp. 36-57. DOI: 10.20472/TEC.2019.007.004.

Fúzi, B. and SUPLICZ, S. (2016). The Indicators of the Quality and Changes of Teachers' Work. Universal Journal of Educational Research, 4:8 pp. 1815-1827. Paper: DOI: 10.13189/ujer.2016.040811.

Hrubos, I. (2014). Verseny - értélekés - rangsorok [Competition - Evaluation Rankings]. Educatio, 2014/4. pp. 541-549. ISSN 1216-3384.

Kálmán, O. (2004). A hallgatók tanulási sajátosságainak változásai a felsőoktatás évei alatt [Changes in Learning in Higher Education]. Magyar Pedagógia, Vol. 104. No. 1. pp. 95-114.

Khalid, A. (2013). Improving Student Interest in Engineering Curricula - Exciting Students about their Classes. Universal Journal of Educational Research 1(1): 20-25, DOI: 10.13189/ujer.2013.010103

Lubicz-Nawrocka, T. and Bunting, K. (2019). Student perceptions of teaching excellence: an analysis of student-led teaching award nomination data. Teaching in Higher Education, 24:1, 63-80, DOI: 10.1080/13562517.2018.1461620.

Magyari, G. (2010). Hogyan tanulnak a ma középiskolásai - a holnap egyetemistái [How Do the Secondary School Students of Today Learn? - The University Students of 
Tomorrow]. In DOBÓ, I., PERJÉS, I., TEMESI, J. (eds.) Korszerú felsőoktatási pedagógiai módszerek, törekvések [Modern Pedagogical Methods and Intentions in Higher Education]. Konferencia-előadások. NFKK Füzetek 5. Corvinus, Budapest, pp. 32-39.

NUS Student Experience Report (2008) https://www.nus.org.uk/PageFiles/4017/NUS_ StudentExperienceReport.pdf.

Simándi, S. (2016). Fiatal és felnőtt hallgatók a felsőoktatásban [Young and Adult Students in the Higher Education - Methodological Approaches and Challenges in the Higher Education]. A felsőoktatás módszertani vetületei és kihívásai. EKF, Líceum Kiadó, Eger, 130 p. ISBN 978-615-5509-95-7

Solt, K., Lévai, R. S. and Szczuka, B. (2018). A lemorzsolódás okai és csökkentésére tett intézkedések a Budapesti Gazdasági Egyetemen [Reasons of the Drop Out and Actions Against It at the Budapest Business School]. In print. VIII. Trefort Ágoston Szakképzésés Felsőoktatás-pedagógiai Konferencia. 